\title{
Діагностика та визначення тактики хірургічного лікування ускладнених форм хронічного панкреатиту
}

\author{
A. I. SUKHODOLIA, O. O. PIDMURNYAK, S. A. SUKHODOLIA, O. I. TROPARCHUK, O. I. KOLOMIIETS \\ M. Pyrohov Vinnytsia National Medical University \\ Khmelnytskyi Regional Hospital
}

\section{DIAGNOSTICS AND IDENTIFICATION OF SURGICAL TREATMENT TACTICS OF COMPLICATED FORMS OF CHRONIC PANCREATITIS}

\begin{abstract}
Узагальнено досвід хірургічного лікування 176 пацієнтів з ускладненим перебігом хронічного панкреатиту. Залежно від виду ускладнень, локалізації процесу, стану панкреато-біліарної зони за допомогою запропонованої нами інтраопераційної пункційної панкреатовірсунгографії виконували інвазивну діагностику стану протокової системи та тканини підшлункової залози. Це дало нам змогу діагностувати різні ускладнення ХП та виконати найоптимальніше операційне втручання, 3 найменшими післяопераційними ускладненнями. Враховуючи прогресування процесу в підшлунковій залозі, наростання екзокринної недостатності, що підтверджується визначенням рівня фекальної еластази-1, хірургічні ускладнення хронічного панкреатиту виникають у різні терміни. Застосування розробленої інтраопераційної діагностики ураження протокової системи підшлункової залози, а саме пункційної панкреатовірсунгографії, забезпечило зменшення частоти ускладнень у ранньому післяопераційному періоді, вираження больового синдрому, а також покращення якості життя пацієнтів (за опитувальником MOS SF-36).

The experience of surgical treatment of 176 patients with complicated chronic pancreatitis occurrence was studied. Depending on the type of complications localization process, state-biliary pancreatic area using our proposed intraoperative puncture pancreatovirsungography, performed invasive diagnostics of the ductal system and pancreatic tissue. This enabled us to diagnose the various complications of $\mathrm{CP}$, and implement the most optimal surgery, with minimal postoperative complications. Taking into account the progression in the pancreas, exocrine rise, as evidenced by the definition of fecal elastase-1 surgical complication of chronic pancreatitis occur at different times. Application of developed intraoperative diagnosis of ductal system of the pancreas, namely puncture pancreatovirsungography, ensured the reduction of the frequency of complications in the early postoperative period, severity of pain and improve quality of life (by questionnaire MOS SF-36).
\end{abstract}

Постановка проблеми і аналіз останніх досліджень та публікацій. Хронічний панкреатит (ХП) - запальне захворювання підшлункової залози (ПЗ), що характеризується руйнуванням здорової тканини, розвитком рубцевої фіброзної тканини i, як наслідок, призводить до необоротних морфологічних змін. Подальший розвиток хвороби супроводжується больовим синдромом, розладом функції ПЗ, ускладнюється цукровим діабетом, стеатореєю, втратою маси тіла, що призводить до зниження якості життя пацієнтів з ускладненими формами ХП. 3 часом, внаслідок прогресування хвороби, відбувається наростання екзо- та ендокринної недостатності [1, 2].

Сучасні методи лікування забезпечують тільки тимчасове полегшення, що знижує больовий синдром та відтерміновує розвиток ускладнень ХП, але не в змозі зупинити чи сповільнити прогресування змін у тканині та функціях ПЗ [5]. Загальна частота ХП в Європі становить 6-7 на 100 000, що підтверджує ріст захворюваності за останні десятиріччя. Майже в усіх країнах вчені констатують про переважний алкогольний генез ХП [8], крім того, існує прямий зв'язок між економічним розвитком країни та відсотком урбанізації.

Загальноприйняті симптоми, що супроводжують пацієнтів із ХП, такі як біль в епігастрії, нудота, розлади випорожнення, здуття, все частіше ускладнюються біліарною обструкцією, холангітом, формуванням кіст, вірсунголітіазом, цукровим діабетом, портальною гіпертензією із шлунково-кишковими кровотечами, а в деяких випадках розвитком панкреатоплевральних та внутрішньочеревних нориць із подальшим асцитом та плевритом. Злоякісне переродження ПЗ у пацієнтів із ХП спостерігається у п'ять разів частіше, що часто спричиняє труднощі у диференційній діагностиці цих двох захворювань $[1,6]$. Варто відзначити про 
наявність так званої “безбольової форми ХП”, що можлива навіть при тяжкій екзо- та ендокринній недостатності. Вона підтверджується після проведення діагностичних функціональних тестів ПЗ, таких як: визначення фекальної еластази-1, прихованого жиру та трипсину в калі. За останніми даними, екзокринна недостатність ПЗ, при якій виникає стеаторея, розвивається при 90 \% заміщенні здорової тканини ПЗ. Досі не існує загальноприйнятого золотого стандарту для діагностики ХП. Жодний інструментальний, радіологічний, клінічний чи ендоскопічний інструмент не може остаточно та повною мірою діагностувати ХП [7].

Таким чином, збільшення кількості хворих на ускладнені форми ХП, чисельні морфологічні зміни ПЗ при них, відсутність єдиного погляду щодо діагностики та найбільш раціонального способу операційного втручання, спрямованих на максимальне збереження функції ПЗ, зменшення клінічних проявів ускладнених форм ХП та кількості післяопераційних ускладнень, а також поліпшення якості життя оперованих пацієнтів, дають підстави розробляти та впроваджувати методи діагностики ускладнень у хворих на ХП.

Мета роботи: покращення якості життя прооперованих пацієнтів шляхом диференційованого підходу до діагностики (інвазивної та неінвазивної), операційного етапного втручання та післяопераційного ведення пацієнтів з ускладненими формами хронічного панкреатиту.

Матеріали і методи. Наша робота базується на ретроспективному та проспективному аналізі результатів хірургічного лікування 176 хворих на ускладнені форми ХП, розподілених згідно з класифікацією M. Buchler та співавт. (2009): критерії залучення - хворі на ХП зі стадіями В та С.

Серед оперованих пацієнтів більшість чоловіків - 67,3 \%, жінок було 32,7 \%, серед яких віком до 50 років було 58,5 \% (103 хворих), тобто більшість оперованих пацієнтів - люди працездатного віку, що свідчить про соціальний аспект проблеми, яка розглядається. Кількість післяопераційних ускладнень становила 16,5 \%, а загальна летальність - 5,3 \%.

Основною причиною виникнення ХП у 130 (74 \%) хворих був алкоголь; у 40 (23 \%) мав місце біліарний генез; у 6 (3 \%) - ідіопатичний ХП.

Тривалість захворювання на ускладнені форми ХП становила від 2 до 10 років. Більшість пацієнтів переносила неодноразові атаки гострого панкреатиту, що в результаті сприяло виникненню хронічного процесу з усіма наступними ускладненнями [3].

Незважаючи на сучасні методи діагностики (УЗД, MCKT, MPT, Ro, ЕРХПГ), а також їх доступність, що наявна у лікувальних закладах III рівня надання допомоги, встановлення діагнозу ХП все ж залишається складним і дещо запізнілим. Велика кількість таких пацієнтів продовжує систематичне лікування у терапевтичних відділеннях, де отримує тільки тимчасове полегшення стану і відтермінування операційного втручання. Тому вважаємо найбільш ефективним та специфічним методом діагностики ускладнених форм ХП визначення фекальної еластази-1 [2, 7] як показника екзокринної недостатності ПЗ. Як відомо, клінічні ознаки екзокринної недостатності проявляються тільки після значної їі втрати. Даний метод включений у діагностичний скринінг та застосовується як в амбулаторних пацієнтів, так i в пацієнтів, що перебувають у хірургічному стаціонарі. До інвазивних інтраопераційних методів діагностики ХП в обов’язковому порядку пропонуємо впровадити інтраопераційну пункційну панкреатовірсунгографію (рис. 1, 2).

Методика інтраопераційної пункційної панкреатовірсунгографії виконується таким чином. Після входження у велику сальникову сумку шляхом розсічення шлунково-ободової зв'язки мобілізували ПЗ. Як правило, у більшості пацієнтів за ускладненого ХП існує протокова гіпертензія, тому пальпаторно виявити протоку ПЗ не складно. Відзначають іï̈ випинання, при пальпації - незначну флуктуацію чи пролабування. Якщо це не вдається зробити пальпаторно, протоку ПЗ можна пунктувати чи здійснити поперечні косі розрізи. Далі виконували пункцію та аспірували панкреатичний сік в об’ємі, що приблизно відповідатиме об’єму введеної контрастної речовини. Попередньо лікар-анестезіолог внутрішньовенно вводив 200 мкг октреостатину для попередження загострення панкреатиту. Водорозчинну контрастну речовину (тріомбраст 76 \%) розводили 0,5 \% розчином новокаїну у співвідношенні 1:1. Розчин вводили в протоку шприцом, поступово натискаючи на поршень. Як правило, для результатив-

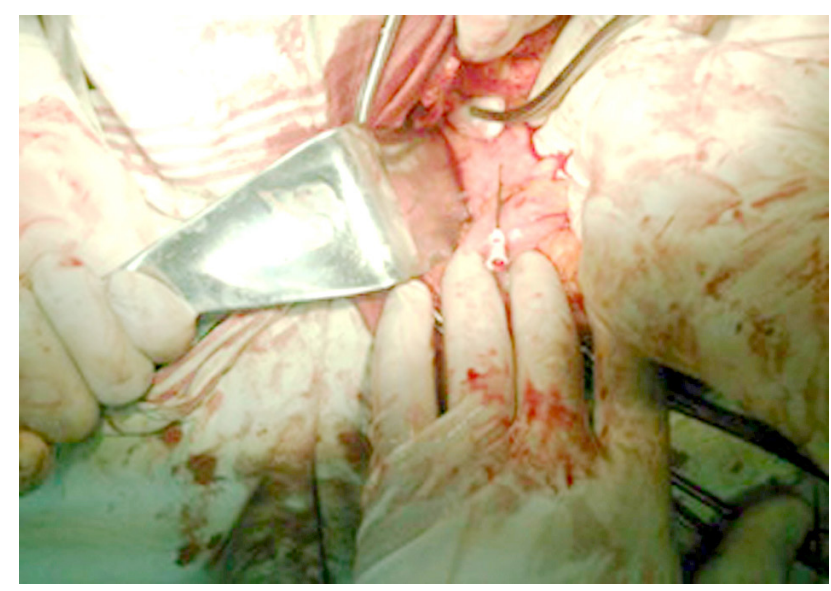

Рис. 1. Катетеризація протоки ПЗ. 


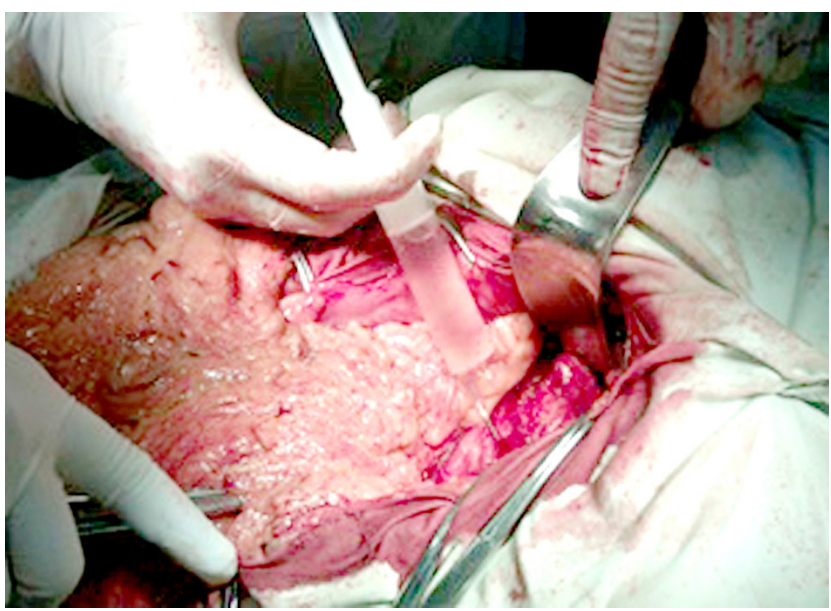

Рис. 2. Введення контрасту.

ної панкреатовірсунгографії вистачало 20 мл контрасту. Через 1 хв проводили інтраопераційну рентгенографію, -скопію.

Метод $є$ новим і раніше в літературі не описувався. Тому його було описано та отримано патент на корисну модель № 101656, Бюл. № 18 від 25.09.15 p. [7].

При правильному виконанні даного обстеження ми отримуємо контрастовану протоку ПЗ на всьому протязі, візуалізуються панкреатичні озера (рис. 3), конкременти при наявності сполучення $з$ кістою (рис. 4) або виході контрастної речовини за межі ПЗ, що свідчить про наявність нориці (черевної або панкреатоплевральної).

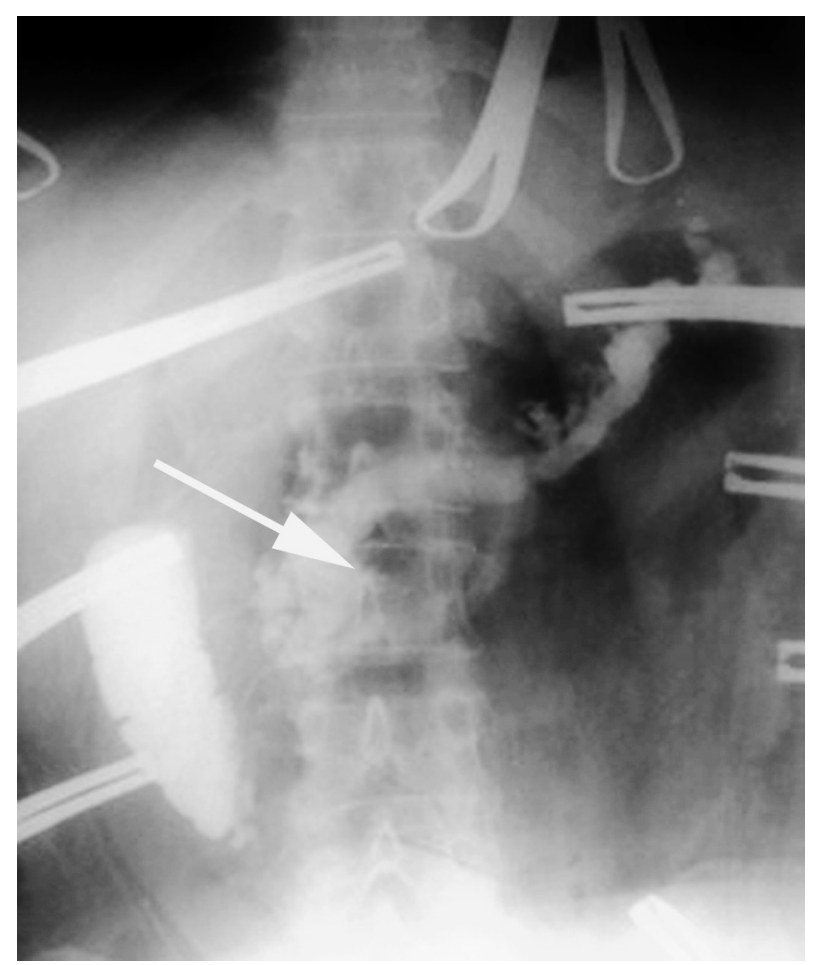

Рис. 3. Контрастована розширена протока ПЗ з гіпертензією та норицею.

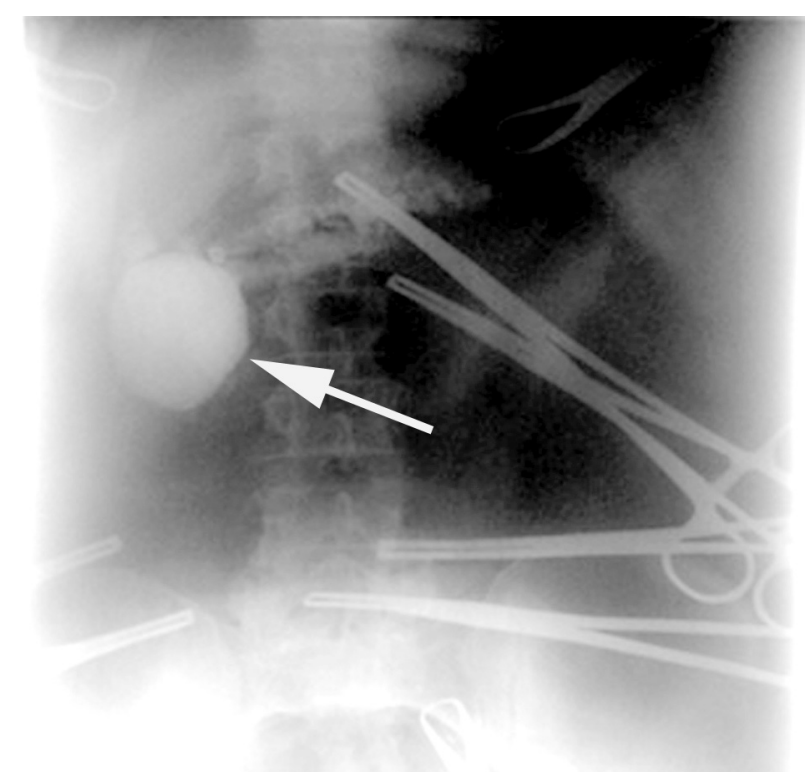

Рис. 4. Розширена протока ПЗ сполучається з порожниною кісти.

При фіброзних змінах головки ПЗ спостерігається стеноз ДПК, що підтвердить відсутність контрасту в наступній. На нашу думку, даний метод є найбільш інформативним та дозволяє виконати найефективніше операційне втручання та попередити ускладнення.

Результати досліджень та їх обговорення. 3 метою діагностики нориць (внутрішньоочеревинних та черевноплевральних) ПЗ, протокової гіпертензії, сполучення протоки ПЗ з кістою ми впровадили спосіб інтраопераційної діагностики змін протокової системи ПЗ (рис. 3). У дослідження включено 76 пацієнтів, у яких виявлено кісти (головки, тіла, хвоста) ПЗ; хворих розподілено на дві групи.

У 32 (42 \%) пацієнтів (група порівняння) здійснено зовнішнє або внутрішнє (цистодуоденоанастомоз, цистогастроанастомоз) дренування кіст ПЗ.

У 44 (58 \%) пацієнтів (основна група) проведено інтраопераційну пункційну панкреатовірсунгографію, що дозволило у 33 (75 \%) з них виявити кісту, що сполучалася з протокою ПЗ (рис. 4), та значну протокову гіпертензію.

Поздовжню панкреатоцистоєюностомію (операція Пєстова) виконано у 23 (70 \%) пацієнтів, операцію Фрея - у 7 (21 \%), операцію Бегера - у 3 (9 \%). Тривалість спостереження - від 6 до 24 міс.

Оскільки у пацієнтів групи порівняння протокова гіпертензія не ліквідувалась, у 20 (62,5 \%) пацієнтів з часом виникли рецидиви, збільшилася інтенсивність больового синдрому, у 10 (31 \%) - сформувалася зовнішня тривала нориця ПЗ, що потребувала повторних операційних втручань (рис. 5). У 8 (25 \%) пацієнтів у віддаленому піс- 


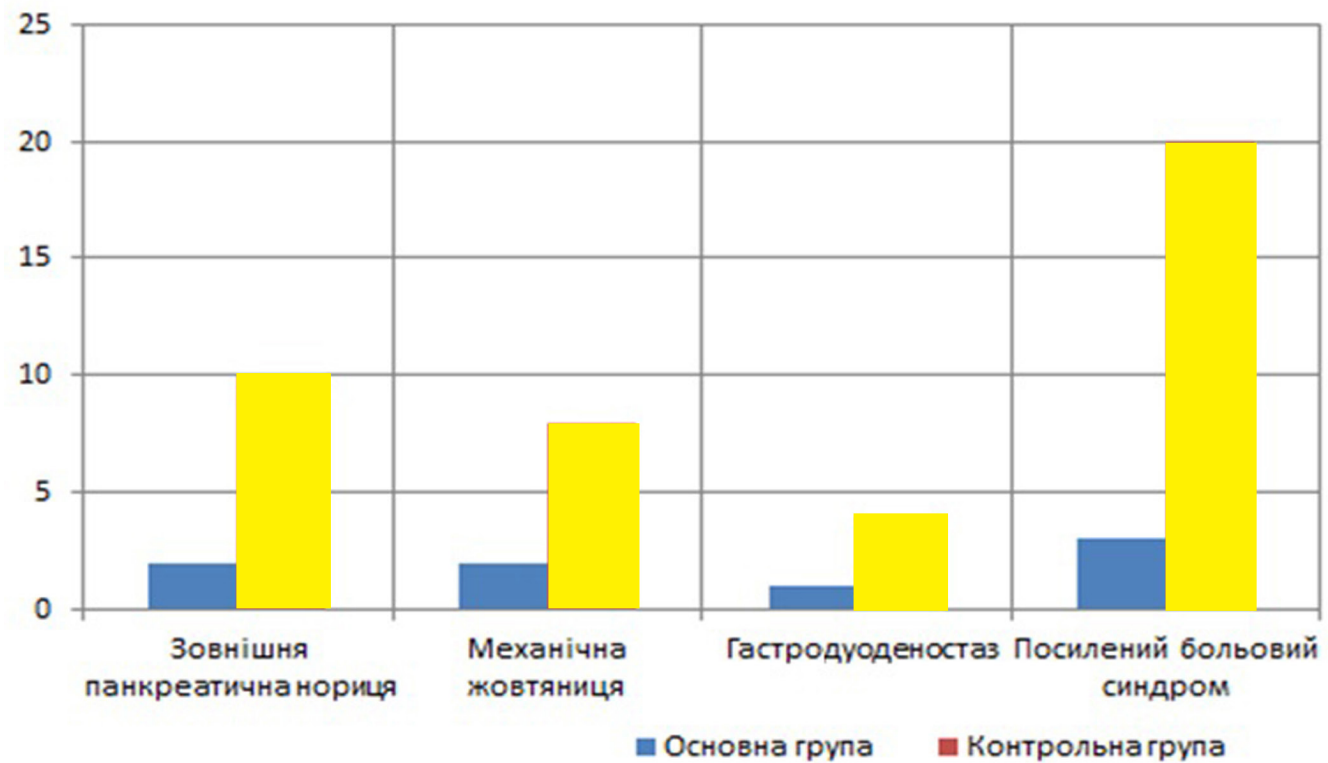

Рис. 5. Післяопераційні ускладнення прооперованих хворих.

ляопераційному періоді виникла механічна жовтяниця. В основній групі ускладнення після операції Пєстова виникли у 2 (4,5 \%) хворих (нориця П3), що з часом ліквідувались, решта відзначала поліпшення якості життя за даними опитувальника MOS SF-36.

Проведення інтраопераційної пункційної панкреатовірсунгографії дало можливість визначити стан протокової системи ПЗ і, залежно від цього, застосувати найбільш ефективний метод операційного втручання. За інформативністю діагностики захворювань органів панкреатогепатобіліарної зони метод зіставний з ендоскопічною ретроградною холангіопанкреатографією, проте він є більш безпечним та простим у виконанні. Слід пам'ятати, що ці методи не $є$ конкуруючими, а доповнюють один одного під час встановлення діагнозу.

Застосування запропонованої тактики дозволило попередити виникнення рецидивів та покращити якість життя оперованих пацієнтів.

\section{СПИСОК ЛІТЕРАТУРИ}

1. Хронический панкреатит - современные концепции патогенеза, диагностики и лечения / [А. А. Шалімов, В. В. Грубнік, Джоел Горовиц и др.]. - К. : Здоров’я, 2000. - 255 с.

2. Етапні хірургічні втручання при ускладненому хронічному панкреатиті / А. І. Суходоля, В.В.Петрушенко, О. О. Підмурняк [та ін.] // Харківська хірургічна школа. 2013. - № 2. - C. 85-88.

3. Суходоля С. А. Обгрунтування диференційованого підходу до хірургічного лікування ускладнених форм хронічного панкреатиту : автореф. дис. на здобуття наук. ступеня канд. мед. наук / Суходоля С. А. ; Національна академія медичних наук України, ДУ “Національний інститут хірургії та трансплантології імені О. О. Шалімова”. - К., 2016. - 20 с.

4. Пат. 101656 Україна. МПК А61В 17/34. Спосіб інтраопераційної пункційної панкреатовірсунгографії / С. А. Суходоля, В. В. Петрушенко, А. І. Суходоля, О. В. Коломієць (Україна).
Таким чином, інтраопераційна пункційна панкреатовірсунгографія є інформативним та ефективним інвазивним методом дослідження протокової системи ПЗ у пацієнтів за ускладнених форм ХП, що дозволило застосувати найефективніший метод операційного лікування у конкретного пацієнта.

Висновки. 1. Інтраопераційна пункційна панкреатовірсунгографія у комплексній діагностиці дозволила диференціювати тип змін протокової системи підшлункової залози у хворих з ускладненим ХП та виявити у 64 \% стриктуру протоки, у 43,4 \% сполучення кісти з протокою П3, у 4 \% наявність внутрішньої нориці ПЗ.

2. Застосування інтраопераційної пункційної вірсунгографії значно полегшує вибір методу операції та, як наслідок, забезпечує кращий результат операційного втручання при ускладнених формах ХП, особливо у хворих із кістами та норицями підшлункової залози.

- № u201502823 ; заявл. 27.03.15 ; опубл. 25.09.15, Бюл. № 18. 5. American Pancreatic Association Practice Guidelines in Chronic Pancreatitis: evidence-based report on diagnostic guidelines / D. L. Conwell, L. S. Lee, D. Yadav [et al.] // Pancreas. 2014. -Vol. 43. - P. 1143-1162.

6. Giger U. Management of chronic pancreatitis / U. Giger, Z. Stanga, M. H. DeLegge // Nutr. Clin. Pract. - 2004. - Vol. 19. - P. 37-49.

7. Chronic pancreatitis: A diagnostic dilemma / Hazel M. Ní Chonchubhair, Oladapo Lawal, Donal B O’Connor, Kevin C Conlon // World J. Gastroenterol. - 2016. - Vol. 22(7). - P. 2304-2313.

8. The seventh nationwide epidemiological survey for chronic pancreatitis in Japan: clinical significance of smoking habit in Japanese patients / M. Hirota, T. Shimosegawa, A. Masamune [et al.] // Pancreatology. - 2014. - Vol. 14. - P. 490-496.

Отримано 12.05.16 